\title{
PLANTING DATE EFFECTS ON OIL YIELD IN SUNFLOWER (Helianthus annuus L.)
}

\author{
Balalić $^{1 *}$ I., Crnobarac ${ }^{2}$, J. and Dušanić ${ }^{1}$, N.
}

${ }^{1}$ Institute of Field and Vegetable Crops, Maksima Gorkog 30 ,

21000 Novi Sad, Serbia

${ }^{2}$ Faculty of Agriculture, Institute of Field and Vegetable Crops,

Trg D. Obradovica 8, 21000 Novi Sad, Serbia

Received: October 10, 2006 Accepted: May 15, 2007

SUMMARY

Oil yield per unit area is the ultimate target in growing high-oil sunflower genotypes. A research was carried out to determine planting date effects on oil yield, using three sunflower hybrids (Miro, Rimi, Pobednik), eight planting dates and two vegetation periods. The experiment used the RCB design with four replications. Oil yield as product of grain yield and oil concentration was expressed in $\mathrm{kg} / \mathrm{ha}$. Oil yield was predominantly influenced by the year of growing $(91.5 \%)$. The influence of planting date on yield amounted to $4.3 \%$. All sources of variation were highly significant, except hybrid and interaction hybrid $\times$ year. On average, the hybrid Rimi had the highest mean value for oil yield. Oil yield was higher in 2004 than in 2005.

Key words: sunflower, planting date, seed yield, oil yield, climatic conditions

\section{INTRODUCTION}

Sunflower (Helianthus annuus L) is currently the world's fourth largest oilseed crop (de Rodriguez et al., 2002). In Serbia sunflower is the main oilcrop. For successful production of edible oil, hybrids are needed which are capable of providing high grain production, i.e., high production of oil per unit area. Oil yield per unit area is the ultimate target in growing high-oil sunflower genotypes. Oil yield is also affected by other plant characters. Among these, the most important are plant number per unit area, number of grains per plant, hectoliter mass, 100-grain weight, husk content, oil content in grain and grain yield (Joksimović et al., 1999).

The aim of this study was to evaluate the effect of planting date on oil yield in sunflower.

* Corresponding author: tel/fax 0038121413833 e-mail: igorb@ifvcns.ns.ac.yu 


\section{MATERIAL AND METHODS}

In order to investigate the influence of planting date on oil yield in sunflower, three hybrids were chosen: Miro, Rimi and Pobednik. They were grown during two vegetation periods $(2004,2005)$ at the experiment field of Institute of Field and Vegetable Crops, Oil Department, Novi Sad. The hybrids were sown at eight different planting dates (in 10-day intervals from 20 March to 1 June). The experiment used the RCB design with four replications. Oil yield as product of grain yield and oil concentration was expressed in $\mathrm{kg} / \mathrm{ha}$.

Data were processed by means of STATISTICA 7.0.

\section{RESULTS AND DISCUSSION}

Highly significant differences were found for all sources of variation, except for hybrids and interaction hybrid $\times$ year (Table 1$)$.

Table 1: ANOVA for oil yield in sunflower (2004, 2005)

\begin{tabular}{|c|c|c|c|c|}
\hline Source of variation & Df & MS Value & & $\mathrm{F}_{\mathrm{e}}$ \\
\hline Hybrid $(\mathrm{H})$ & 2 & 83133 & 0.69 & $2.83^{\mathrm{NS}}$ \\
\hline Planting date $(\mathrm{P})$ & 7 & 505089 & 4.27 & $17.21^{\star *}$ \\
\hline Year $(Y)$ & 1 & 10823010 & 91.54 & $368.71^{* *}$ \\
\hline $\mathrm{H} \times \mathrm{P}$ & 14 & 101322 & 0.86 & $3.45^{\star \star}$ \\
\hline$H \times Y$ & 2 & 45229 & 0.38 & $1.54^{\star \star}$ \\
\hline$P \times Y$ & 7 & 176953 & 1.50 & $6.03^{* *}$ \\
\hline$H \times P \times Y$ & 14 & 59413 & 0.50 & $2.02^{\star \star}$ \\
\hline$E$ & 144 & 29353 & & \\
\hline
\end{tabular}

Oil yield was predominantly influenced by the year of growing (91.5\%). The influence of planting date on yield amounted to $4.3 \%$ (Table 1). Our results are in agreement with the findings of de la Vega and Hall (2000) who claimed that planting date was the main source of variation for oil yield. In their experiment oil yield varied from $817 \mathrm{~kg} / \mathrm{ha}$ (sowing in December) to $2300 \mathrm{~kg} / \mathrm{ha}$ (sowing in October) on average for two years in the conditions of Argentina. Ekin et al. (2005) found that, on average over experiment years, oil yield ranged from $0.66 \mathrm{t} / \mathrm{ha}$ to $1.58 \mathrm{t} / \mathrm{ha}$ in Van region, Turkey. It was shown that oil yield was affected by cultivar and year. In a three-year trial, using hybrids Dukat, Velja and Krajišnik, Balalić et al. (2006) found that the contribution of year to oil yield was $76 \%$, and of planting date $3.9 \%$.

Oil yield was higher in the first year of the experiment (2004) than in the second (2005) for all hybrids and on the average for all planting dates (Figures 1 and 2). This was due to the inconvenient climatic conditions in 2005. The highest oil yielding hybrid in both years was hybrid Rimi (Figure 3).

Taking into account the average two-year oil yields it can be seen that Rimi and Pobednik reached maximum values at the sixth planting date (30 April). Miro, the 


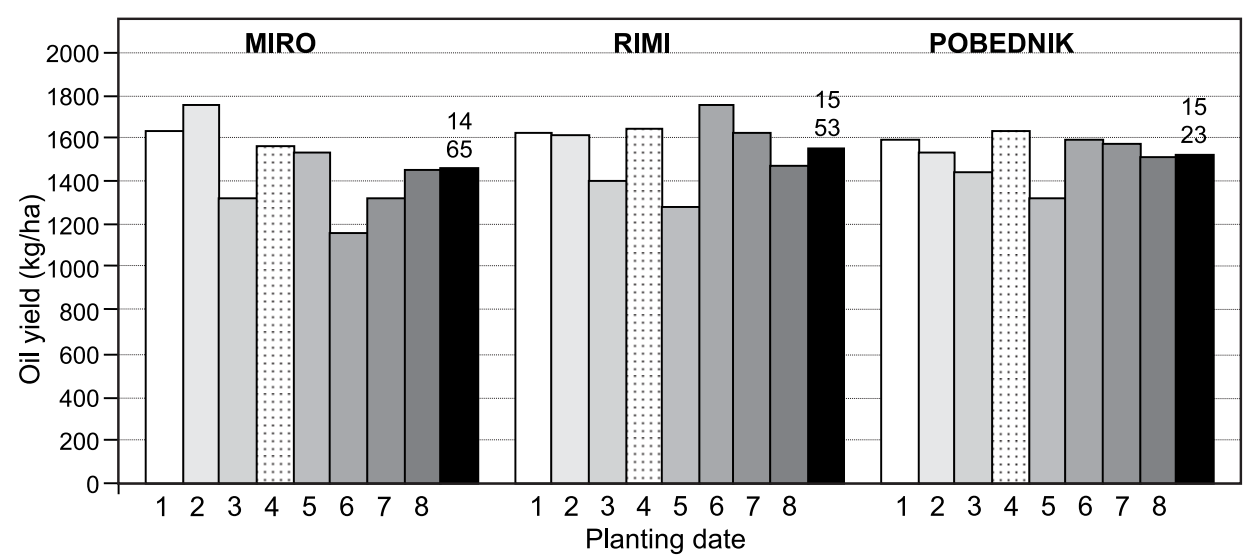

Figure 1: Oil yield of sunflower (2004).

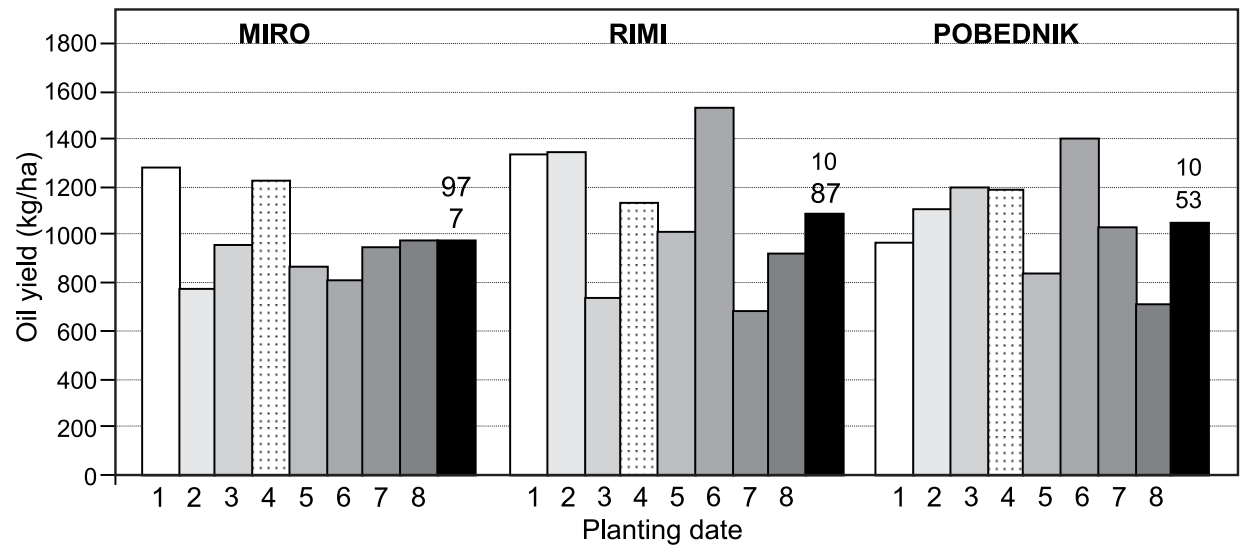

Figure 2: Oil yield of sunflower (2005).

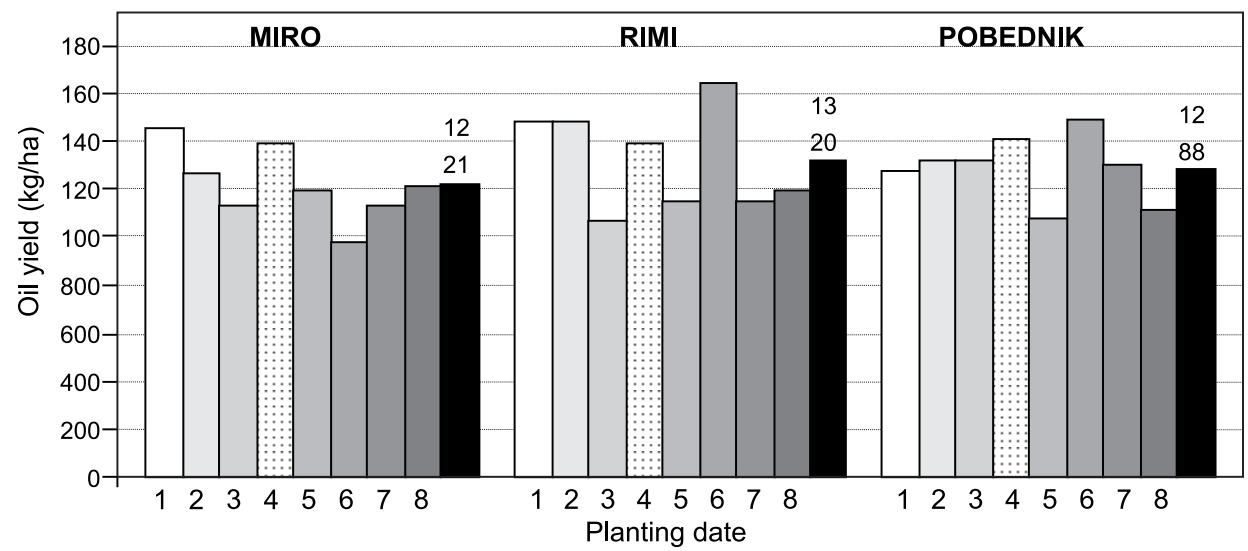

Figure 3: Oil yield of sunflower (2004, 2005). 
hybrid with lowest oil yield, showed the highest mean values in the first (20 March) and fourth (10 April) planting date (Figure 3).

Crnobarac et al. (1996) found a significant effect of planting date on oil yield in a two-year experiment $(1994,1995)$. The maximum oil yield was reached in the III, IV and V planting dates (10 April, 20 April and 1 May, respectively). After that, the oil yield decreased, reaching the lowest value in last planting date (1 June).

\section{REFERENCES}

Balalić I., Crnobarac J., and Dušanić, N., 2006. Efekat rokova setve na sadržaj i prinos ulja kod suncokreta. Zbornik radova: Proizvodnja i prerada uljarica. 47. Savetovanje uljara, Herceg-Novi, pp. 49-54.

Crnobarac J., Dušanić N., i Ćupina, T., 1996. Mogućnost povećanja i stabilizacije prinosa kod suncokreta. Zbornik radova, Nau ni institut za ratsrtvo i povrtarsvo, Novi Sad, 25:13-26. de la Vega A.J., and Hall, A.J., 2002. Effect of planting date, genotype, and their interaction on sunflower yield. II. Components of oil yield. Crop Sci. 42:1202-1210.

de Rodriguez, D.J., Romero-Garcia J., Rodriguez-Garcia R., and Angulo-Sanchez, J.L., 2002. Characterization of proteins from sunflower leaves and seeds: Relationship of biomass and seed yield. In: Trends in New Crops and New Uses (Janick, J. and A. Whipkey, eds). Proc. AAIC Fifth National Symposium, Purdue Univ., USA, pp. 143-149.

Ekin Z., Tuncturk M., and Yilmaz, I., 2005. Evaluation of seed yields and yield properties of different sunflower (Heliathus annuus L.) hybrid varieties in Van, Turkey. Pakistan J. Biolog. Sci. 8:683-686.

Joksimović J., Atlagić J., and Škorić D., 1999. Path coefficient analysis of some oil yield components in sunflower (Heliathus annuus L.). Helia, 22(31):35-42.

\section{INFLUENCIA DE LA FECHA DE SIEMBRA EN EL RENDIMIENTO DE ACEITE EN GIRASOL (Helianthus annuus L.)}

\section{RESUMEN}

El rendimiento de aceite por unidad de superficie representa el objetivo final de cultivación de los tipos de girasol alto oleicos. Las investigaciones fueron emprendidas con el fin de determinar la influencia de la fecha de siembra en el rendimiento de aceite. Fueron utilizados tres híbridos de girasol (Miro, Rimi, Pobednik), ocho fechas de siembra y dos períodos vegetativos. En los experimentos fue utilizado el método $\mathrm{RCB}$ en cuatro repeticiones. El rendimiento de aceite, como producto de rendimiento de semilla y la concentración de aceite, era expresado en $\mathrm{kg} / \mathrm{ha}$. $\mathrm{El}$ rendimiento de aceite mayoritariamente estuvo bajo la influencia del año de cultivación (91,5\%). La influencia de la fecha de siembra logró el valor de $4,3 \%$. Todas las fuentes de variación fueron altamente significantes, con excepción de los híbridos e interacción de híbrido $\times$ año. En el promedio, el más alto rendimiento de aceite fue anotado en el híbrido Rimi. El rendimiento de aceite fue más alto en el ao 2004 que en el año 2005. 


\title{
INFLUENCE DE LA DATE DES SEMAILLES SUR LE RENDEMENT D'HUILE DU TOURNESOL (Helianthus annuus $\mathbf{L}$.)
}

\author{
RÉSUMÉ
}

Le rendement d'huile par unité de surface est le but ultime de la culture des génotypes de tournesol à haute teneur en huile. Des recherches ont été entreprises pour déterminer l'influence de la date des semailles sur le rendement d'huile. Trois hybrides de tournesol (Miro, Rimi, Pobednik) ont été utilisés, huit dates de semailles et deux périodes de végétation. La méthode RCB a été utilisée lors des expériences avec quatre répétitions. Le rendement d'huile en tant que produit du rendement de graines et de concentration d'huile a été exprimé en $\mathrm{kg} / \mathrm{ha}$. Le rendement d'huile était généralement sous l'influence de l'année de culture $(91,5 \%)$. L'influence de la date des semailles a atteint la valeur de $4,3 \%$. Toutes les sources de variation ont été hautement significatives avec l'exception de l'hybride et de l'interaction hybride $\mathrm{x}$ année. En moyenne, le plus grand rendement en huile a été notée dans l'hybride Rimi. Le rendement en huile était plus élevé en 2004 qu'en 2005. 